\title{
EDITORIAL
}

\section{Launching a Journal About and Through Students as Partners}

\author{
Anthony Cliffe, ${ }^{a}$ Alison Cook-Sather, ${ }^{b}$ Mick Healey, ${ }^{c}$ Ruth Healey, ${ }^{d}$ Beth Marquis, ${ }^{e}$ Kelly E \\ Matthews, ${ }^{f}$ Lucy Mercer-Mapstone, ${ }^{f}$ Anita Ntem, ${ }^{b}$ Varun Puri, ${ }^{e}$ and Cherie Woolmer ${ }^{e}$ \\ The Editorial Board, ${ }^{1}$ International Journal for Students as Partners \\ a Department of Education, Liverpool John Moores University, Liverpool, UK \\ b Bryn Mawr College, Bryn Mawr, PA, USA \\ c University of Gloucestershire and Healey HE Consultants, Howden, East Riding of Yorkshire, UK \\ ${ }^{\mathrm{d}}$ Department of Geography and International Development, University of Chester, Chester, UK \\ e MacPherson Institute, McMaster University, Hamilton, Ontario, Canada \\ f University of Queensland, St Lucia, 4072, Brisbane, Queensland, Australia
}

Contact: $\underline{\text { mhealey@glos.ac.uk }}$

Welcome to the first issue of the International Journal for Students as Partners (IJSaP). We are delighted to publish four research articles, three reflective essays, four case studies and an opinion piece, alongside this editorial and two book reviews. Together these contributions have been written by 21 students and 28 staff from four different countries. In the spirit of partnership that underpins IJSaP, this inaugural editorial was co-written by the 10 students and staff who comprise the Editorial Board.

VISION

Our vision is that IJSaP will provide a space that captures the energies, debates, controversies, benefits, challenges, uncertainties, emotions, evidence, and bold ideas that arise when we shift the traditional dynamics of learners and educators in higher education toward partnership. In creating and maintaining this space, we hope to support forms of inquiry into partnership that we cannot predict or imagine and to contribute to the transformation of how learning happens.

While we recognise that there are other journals that address issues around Students as Partners, we feel that IJSAP is distinctive in a combination of ways. Not only did we want to develop a high-quality, open-access, international, research-based journal, we also aspired to challenge traditional views about what a journal is, in terms of both content and operational processes. We aim to affirm a wide variety of genres for writing about partnership-research articles, case studies, opinion pieces, reflective essays, and reviews - that are each valued 
independently but also generate further insight through their juxtaposition. Beyond embracing such diverse genres, IJSaP seeks to consider new ways of "doing" - that is, "walking the talk" of partnership. Therefore, leadership is provided by an international editorial team of staff and students working both in country-based, student-staff pairs and as an international collaborative. We are committed to having submissions reviewed by students as well as staff.

Making space for a community of scholars-academics, staff, and students - to understand and unpack what "students as partners" might mean is central to IJSaP. While our beliefs and views as members of the IJSaP Editorial Board are important and will influence the direction of the journal, our key role is to create opportunities for scholars to make sense of partnership and to contribute new and expanded conceptions, models, frameworks, and definitions that will grow the field of partnership practice and research. We recognise that Students as Partners is a tentative and emergent area of scholarship. Ensuring that we, as an Editorial Board, advised by our International Advisory Group, are open to changing our views and making space for new perspectives will affect the impact of the journal.

\section{ORIGINS OF THE JOURNAL}

In the last few years, a plethora of articles, reports, books, and conferences have focused on the topic of students as partners in learning and teaching in higher education (see Mercer-Mapstone et al., this issue, for a review of recent literature). The idea for launching a journal dedicated to this topic emerged from discussions in the run-up to, and during, the first International Summer Institute on Students as Partners held at McMaster University in May 2016. Over the two and a half months following this first Summer Institute, three of the facilitators-Mick Healey, Beth Marquis and Kelly Matthews-began to discuss the key features of IJSaP.

Arshad Ahmad, Director of The MacPherson Institute at McMaster University, agreed to provide a home for the journal and support for an editorial manager (a post later filled by Cherie Woolmer). The journal fits well within the vision of the MacPherson Institute, which has Students as Partners as a core feature of its strategic plan. The McMaster University Library Press agreed to publish two issues per year in an open-access format.

We (Mick, Beth, and Kelly) sent out our initial ideas for the journal to over 20 students and staff for comment. The responses we received helped us clarify how we could best achieve our vision. One of the welcome replies came from Alison Cook-Sather, who proposed folding Teaching and Learning Together in Higher Education into IJSaP. Alison and Anita Ntem subsequently joined the Editorial Board as the US-based team to add to the teams we had in Australia (Kelly Matthews and Lucy Mercer-Mapstone), Canada (Beth Marquis and Varun Puri), and the UK (Anthony Cliffe and Ruth Healey). Mick agreed to take on the role of Senior Editor. It is this group of staff and students working in partnership that has put the "flesh on the bones" and has developed the policies and practices of the journal.

\section{THE VALUES UNDERPINNING THE WAY WE RUN IJSAP}

The values that underpin the way we run the journal are those that frame many publications on partnership: respect for, genuine collaboration between, and shared responsibility among those involved in processes of curricular or pedagogical conceptualization,

2 Cliffe, A., Cook-Sather, A., Healey, M., Healey, R., Marquis, E., Matthews, K.E., MercerMapstone, L., Ntem, A., Puri, V., \& Woolmer, C. (2017) Launching a journal about and through Students as Partners. International Journal for Students as Partners 1 (1) 
decision-making, implementation, investigation, or analysis (Cook-Sather, Bovill, \& Felten, 2014); a commitment to relationships in which all involved stand to gain from those processes (Healey, Flint, \& Harrington, 2014); and a mindset that supports such processes and relationships (Matthews, 2016) through embracing an ethic of reciprocity (Cook-Sather \& Felten, 2017).

We have cycled through the excitement and the uncertainty that come with collaboration through partnership as we strive to translate those words into authentic practices. We aim to approach the process of editing IJSaP with a genuine willingness to collaborate in ways that allow for unimagined and unplanned outcomes and with an openness to the new ideas that emerge from the mix of experiences and expertise on the Editorial Board.

In the process of co-imagining and co-creating what the journal might look like, we have grappled with embracing the iterative and reflective process of partnership by being supportive of one another and of submitting authors while also striving to achieve high scholarly standards. Learning and reflection have been at the heart of this process as we seek to listen to, articulate, and embrace "new ways of thinking, learning, and working" (Healey et al., 2014, p. 7) in order to produce an international and multidisciplinary journal that enacts the principles of partnership.

\section{THE IMPORTANCE OF STUDENTS AS PARTNERS}

As an editorial team, we believe that Students as Partners is a contentious and important topic. Anita, for instance, offers the following reflection on this simultaneous significance and difficulty:

Too many times, assumptions are made and protected, such as about who has knowledge about teaching and learning. Not enough teachers think about the ways in which they might challenge their teaching to be as effective as it should be for their students. Noticing the power dynamics that are evident in faculty and student relationships ... is [an] almost forbidden and unheard of to challenge them. Students as Partners, however, challenges those dynamics and provides insight into what faculty may not always realize. Students become liaisons through which partners can challenge traditional norms and create a platform for affirmation, continuity of what works, and exploration of areas for growth. (Ntem, 2017)

Teaching is most fruitful when students co-create their educational experiences. A growing body of research extends this embrace of student voice (Frison \& Melacarne, 2017; Seale, Gibson, Haynes, \& Potter, 2015) into the notion of Students as Partners (Bovill \& Felten, 2016).

Bringing multiple voices into dialogue and working in partnership is a complicated business (Mercer-Mapstone, Dvorakova, Groenendijk, \& Matthews, in press). The notion of partnership can be taken up and deployed in different ways that often seem at odds with one another-for instance, in ways that align with the radical visions of critical pedagogy (O'Neill \& McMahon, 2012) and in ways that some might view as supporting or playing into instrumentalist, neoliberal discourses (Neary, 2014). The significance and difficulty of this work 
also lies in the ways in which it can resonate with questions of equity and inclusion: how we destabilise hierarchies and invite new voices into dialogue about teaching and learning while simultaneously wrestling with questions about which voices are included and how power continues to be manifested (Bovill, Cook-Sather, Felten, Millard, \& Moore-Cheery, 2016). Linked to the different ways "students as partners" can be taken up and deployed, and for what purposes, are questions about language. For example, why do we use the term "students as partners" and not "staff as partners"? What are the resonances with and/or distinctions from related terms, such as "student engagement"? Questions also arise about what kinds of collaborative relationships fall under the partnership umbrella. In other words, does a partnership need to include students and staff, or does the field of Students as Partners also consider student-student partnerships, partnerships with community, and so on? Such questions both reflect the difficulties and uncertainties of partnership and offer compelling openings for further research and discussion.

The editorial team for IJSAP is keen to avoid normative definitions of partnership as we recognise the emerging nature of debate and practice in the sector. Whilst accepting the need for a plurality of views on "what partnership is and might be," we subscribe to a collection of characteristics that we believe should be evident in partnership-based approaches. We embrace Students as Partners in terms of a broad set of deep principles and values - not a set of rules or prescriptions - that guide creative practices that seek to re-imagine learning interactions as more egalitarian relationships between teachers and learners (Matthews, CookSather, \& Healey, in press) in the most inclusive sense of those terms. These principles and values comprise the presence of multiple voices and perspectives, an emphasis on co-creation, and evidence of students collaborating with, not just helping, staff.

To us, Students as Partners asserts a "radical collegiality" (Fielding, 1999) and constitutes intergenerational learning and democratic fellowship (Fielding, 2011) between students and others in higher education. It is radical in the sense of deeply demanding of change. By advocating Students as Partners, we insist on the inclusion of students among those who can and should shape educational experiences and knowledge generation about teaching and learning in higher education. Our goal is not to displace or devalue any positions or perspectives in higher education, but rather to bring diverse voices into intentional interaction, dialogue, and collaboration.

\section{THE NATURE OF EVIDENCE IN THE STUDENTS-AS-PARTNERS DEBATE}

What constitutes evidence is context specific, and depends on the questions we ask and the answers we value. We aim to make space for differing forms of evidence that might bear meaningfully and rigorously on the wide variety of questions and experiences taken up by scholars investigating partnership. We are open to new ways of challenging or considering what "counts" as evidence. Given that partnership is an evolving and complex set of practices and processes, we steer clear of making broad judgments. We come to each genre of writing and each individual manuscript with our values and principles in mind, but also with a commitment to consider how the methods and approaches deployed fit the questions and issues addressed and how they might contribute to the development of the partnership evidence base more extensively.

4 Cliffe, A., Cook-Sather, A., Healey, M., Healey, R., Marquis, E., Matthews, K.E., MercerMapstone, L., Ntem, A., Puri, V., \& Woolmer, C. (2017) Launching a journal about and through Students as Partners. International Journal for Students as Partners 1 (1) 
We aim to gather evidence of the various and diverse ways that students work as partners with others in higher education as they analyse, develop, and enhance learning and teaching. Not only do we recognise diversity both in the processes of enacting partnership and in writing about those processes, we value these differences and seek points of contact between them. We welcome examples of people wrestling with, as well as celebrating, their partnership work, critically analysing or clarifying the terms and practices associated with partnership, and further complicating both understandings and approaches.

\section{AN EDITORIAL BOARD FUNCTIONING IN PARTNERSHIP}

The Editorial Board works in four student-staff, country-based partnership pairs supported by our senior editor and editorial manager for day-to-day operations, and we meet regularly online as a full board to discuss and wrestle with the bigger issues.

Working as co-editorial pairs and as international collaborators entails the obvious logistical challenges but also requires taking the time to learn about what each of us can contribute to the partnership and recognizing that we "contribute equally, although not necessarily in the same ways" (Cook-Sather et al., 2014, p. 6). As in all partnerships, this learning presents challenges as we come up against our own assumptions and norms and yields insights that almost always emerge through the juxtaposition of different perspectives.

This mixing of perspectives, insights, and experiences has provided many fruitful and, at times, difficult discussions. We have, individually and collectively, needed to take the time to reflect on how we feel the journal should develop. This reflection has been both the challenge and the delight of working in partnership. As Anthony puts it,

Some challenges I have faced are around not so much confidence but a case of selfperceived competence. At first, I didn't think I could contribute or had any weighting behind my views, but l've grown into the role, and support from other Editorial Board members has been useful. It has been a challenge coping with the demands of a new $\mathrm{PhD}$ and being a part of the board. Ultimately, however, it's a great project and journey to be a part of.

\section{COLLABORATING, CONTRIBUTING, AND LEARNING}

To give voice to the multiple considerations that motivated us to join and stay with the Editorial Board, we share some of the board members' inspirations as these reflect the overall spirit of the journal.

Given our willingness to join a team editing a new journal on working in learning and teaching partnerships, it is perhaps unsurprising that we all value learning in collaboration. Lucy points to the particular excitement she felt about "learning about working in partnership with new people in a new context;" about "the intricacies of journal production, editing, and peer review;" and about "collaboration on an international scale." Ruth highlights the value of "learning both from the written submissions, but also through the experience of working with students as partners in the running of the journal itself." Likewise, Varun articulates his hope "to gain a sense of how a journal functions and operates from its conception to its actualization, and to better understand partnership in theory and practice." 
Through IJSaP co-editing, we are learning about working in partnership, the scholarship of partnership, international practices in partnerships, and being journal editors. For several of us, editing a journal is a completely new experience. For others, the new experience is not editing a journal, but co-editing as partners. What emerged from writing about our individual motivations to join IJSaP was the inextricable relationship between our experiences and emotions. Anthony explains that "at first it was very daunting and worrying to be in a completely new and alien academic environment." Cherie names clearly what we have all experienced: "Our approach is demanding (in terms of time and pace) and has felt daunting at times!" And Kelly highlights the energizing aspect of these challenges: "I have enjoyed my collaboration and interactions with folk passionate about partnership. IJSaP promises to keep me connected to such a fun and enjoyable community of peers."

From this collaborative learning adventure, we recognise that we are personally and professionally developing, albeit in different ways, and we are relishing our opportunities to contribute to our co-editorial partnerships and the field of partnership as a broader scholarly movement. Some of us draw on extensive experience; for instance Alison writes: "I wanted to integrate the various ways I have been engaged with partnership work in higher education over the last ten years." Anita, on the other hand, looks forward to how this work will expand for her: "The practice of reading, evaluating, discussing and brainstorming are a few of the major techniques that I continue to sharpen as I know it will help me in my future endeavors as a critical thinker." Mick emphasises the power of both building on past work and moving the field forward: "I wanted to contribute to this movement by being involved in founding a high quality international journal." And Beth highlights the way in which co-creating a new journal on partnership and in partnership offers us a unique "legacy" opportunity: "IJSaP allows us to consider the extent to which partnership practices might inform and alter the ways in which the publishing process, and thus the development and dissemination of knowledge, work."

We are excited to bring partnership into an established academic realm where students and staff collaborating as partners is relatively uncharted territory, and we are eager to see how our co-editing approach opens up new ways of generating and publishing knowledge.

\section{HOW YOU CAN BECOME INVOLVED WITH IJSAP}

By valuing multiple perspectives and different ways of operating, we hope that IJSaP will appeal to a broad group of contributors and readers, including academics, staff, instructors, educational developers, librarians, learning resource specialists, and undergraduate and graduate students.

You can become involved with IJSaP through:

a) Writing for the journal in any of the genres we publish. Please contact us with your ideas. We encourage you to send us (ijsap@mcmaster.ca) your proposals for articles, case studies, or reflective pieces before you submit them.

b) Reviewing for IJSaP. We will provide training for inexperienced reviewers. If you are interested, please complete the reviewer expression of interest form.

c) Telling others about the journal and contributions that you found particularly interesting.

6 Cliffe, A., Cook-Sather, A., Healey, M., Healey, R., Marquis, E., Matthews, K.E., MercerMapstone, L., Ntem, A., Puri, V., \& Woolmer, C. (2017) Launching a journal about and through Students as Partners. International Journal for Students as Partners 1 (1) 
d) Checking that your library lists IJSaP in their catalogue and knowing it is freely available from https://mulpress.mcmaster.ca/ijsap.

We also welcome hearing about your views on the journal and which contributions you find most stimulating and useful. Please send us an email (ijsap@mcmaster.ca). Table 1 gives some quotations from reviewers and authors who have already been in contact.

\section{Table 1: Some responses from reviewers and authors}

"I really appreciate the resources for reviewers that you've set up. It's a great model which I wish more journals would consider." (Reviewer)

"I have reviewed for many journals, conferences and grants. This is the first time I have received a message ... showing how my feedback was incorporated into what was sent to the author(s). And how positive and encouraging your tone [is] to the author(s), while at the same time maintaining rigor." (Reviewer)

"Thank you very much to you and your team for the level of feedback we received on the article we submitted to the International Journal for Students as Partners. I have never received such constructive, detailed, and helpful feedback and wanted to say thank you for the time spent on this to help develop the work." (Author)

"Thank you sincerely for the speedy response and detailed feedback. It helped immensely to receive that preliminary review in advance." (Author in response to feedback on article proposal)

We invite readers to bring both an open and a critical mind to this collaborative endeavor and to add your voices to the debate about terms, practices, theories, and implications of partnership work. We offer the journal as a forum for lively and constructive debate that values a diversity of experiences and perspectives rather than reifying norms and practices that work against radical collegiality.

NOTES

1. The biographies of Editorial Board members are available on the IJSaP website.

2. Among the journals which include aspects of Students as Partners are: International Journal of Student Voice; Student Engagement in Higher Education Journal, Teaching and Learning Together in Higher Education, and The Journal of Educational Innovation, Partnership and Change. 


\section{REFERENCES}

Bovill, C., Cook-Sather, A. Felten, P. Millard, L., \& Moore-Cherry, N. (2016). Addressing potential challenges in co-creating learning and teaching: Overcoming resistance, navigating institutional norms and ensuring inclusivity in student-staff partnerships. Higher Education, 71(2), 195-208.

Bovill, C., \& Felten, P. (Eds.). (2016). Engaging students as partners in learning and teaching: Implications for academic development. International Journal for Academic Development: Special Issue, 21(1), 1-90.

Cook-Sather, A., Bovill, C., \& Felten, P. (2014). Engaging students as partners in learning and teaching: A guide for faculty. San Francisco, CA: Josey-Bass.

Cook-Sather, A., \& Felten, P. (2017). Ethics of academic leadership: Guiding learning and teaching. In F. Su \& M. Wood (Eds.), Cosmopolitan perspectives on academic leadership in higher education (pp. 175-191). London: Bloomsbury.

Fielding, M. (1999). Radical collegiality: Affirming teaching as an inclusive professional practice. Australian Educational Researcher, 26(2), 1-34.

Fielding, M. (2011). Patterns of partnership: Student voice, intergenerational learning and democratic fellowship. In N. Mocker \& J. Sachs (Eds.), Essays in honour of Susan Groundwater-Smith (pp. 61-75). Dordrecht: Springer.

Frison, D., \& Melacarne, C. (2017). Fostering "student voice" to improve teaching \& learning methods in higher education. Teaching and Learning Together in Higher Education, 1(20). Retrieved from http://repository.brynmawr.edu/tlthe/vol1/iss20/6

Healey, M., Flint, A., \& Harrington, K. (2014). Engagement through partnership: Students as partners in learning and teaching in higher education. York: Higher Education Academy. Retrieved from https://www.heacademy.ac.uk/system/files/resources/engagement through partnersh ip.pdf

Matthews, K. E., Cook-Sather, A., \& Healey, M. (in press). Connecting learning, teaching, and research through student-staff partnerships: Toward universities as egalitarian learning communities. In V. Tong, A. Standen, \& M. Sotiriou (Eds.), Research equals teaching: Inspiring research-based education through student-staff partnerships. London: UCL Press.

Mercer-Mapstone, L., Dvorakova, S. L., Groenendijk, L., \& Matthews, K. E. (in press). Idealism, conflict, leadership, and labels: Reflections on co-facilitation as partnership practice. Teaching and Learning Together in Higher Education, 21.

Neary, M. (2014). Student as producer: Research-engaged teaching frames university-wide curriculum development. CUR Quarterly, 35(2), 28-34. Retrieved from http://www.cur.org/DOWNLOAD.ASPX?ID $=3070$

Ntem, A. (2017, May). Resistance and resilience in pedagogical partnership. Roundtable Presentation at the Pennsylvania Consortium for Liberal Arts Pedagogical Partnership Conference, Lafayette College. 
O'Neill, G., \& McMahon, S. (2012). Giving student groups a stronger voice: Using participatory research and action (PRA) to initiate change to a curriculum. Innovations in Education and Teaching International, 49(2), 161-171.

Seale, J., Gibson, S., Haynes, J., \& Potter, A. (2015). Power and resistance: Reflections on the rhetoric and reality of using participatory methods to promote student voice and engagement in higher education. Journal of Further and Higher Education, 39(4), 534552. 